BIOMEDICAL AND BIOSOCIAL ANTHROPOLOGY
$\begin{gathered}\text { Official Journal of the International Academy } \\ \text { of Integrative Anthropology } \\ \text { journal homepage: http://bba-journal.com }\end{gathered}$

\title{
Reorganization of cerebellar cortex structural components one day after experimental thermal injury
}

\section{Ohinska N. V.}

I. Horbachevsky Ternopil National Medical University, Ternopil, Ukraine

\section{ARTICLE INFO}

Received: 18 January 2021

Accepted: 22 February 2021

UDC: $616.831 .7-091.8: 616-001.17]-$

092.9

\section{CORRESPONDING AUTHOR}

e-mail: ohinska@tdmu.edu.ua Ohinska N. V.

\begin{abstract}
Thermal injury is a lesion caused by thermal agents. With deep and large burns, the course of this type of injury becomes a general disease of the whole organism with the involvement of vital organs. The skin is the first to perceive the action of this exogenous factor, and secondarily there are changes in all body systems, in particular in the cerebellum. The aim of our study was to establish micro- and submicroscopic changes in the structural components of the cerebellar cortex one day after the experimental thermal injury. Simulation of experimental thermal injury was performed on white laboratory male rats. Grade III burns were applied under thiopental-sodium anesthesia with copper plates heated in boiled water to a temperature of $97-100^{\circ} \mathrm{C}$. The size of the affected area was $18-20 \%$ of the epilated body surface of rats. The cerebellum was collected after one day, further processing of the material for micro- and submicroscopic examination was performed according to accepted methods. Histological specimens were stained with methylene blue, and for electron microscopy the obtained ultrathin sections were contrasted with uranyl acetate and lead citrate according to the Reynolds method. At the micro- and submicroscopic levels, it was found that 1 day after the experimental thermal injury, reactive changes are observed in neurons, microcirculatory tract and glial cells. Thus, one day after the thermal trauma of the skin, the experimental animals showed the initial violations of the blood-brain barrier of the cerebellar cortex, which are adaptive-compensatory in nature. Initial, destructive, changes in neuro-glialcapillary relations, which occur primarily on their damage to the walls of hemocapillaries and are manifested by a violation of the micro- and ultrastructure of the main cells of the cerebellum - Purkinje, neurocytes of molecular and granular layers, neuroglyocytes, with peri-gliocyocytes were found.

Keywords: neurons, hemocapillaries, cerebellar cortex, thermal injury.
\end{abstract}

\section{Introduction}

Thermal injury is a lesion caused by thermal agents. With deep and significant burns, the course of this type of injury becomes a general disease of the whole organism with the involvement of vital organs $[5,18,20]$. The skin is the first to be damaged by the action of an exogenous burn factor, and secondary changes occur in all body systems $[13,15]$. At thermal defeat, there is a neuro-pain syndrome, and also emergence in blood plasma of burn toxins, peptides of average molecular weight which provoke development of endogenous intoxication and cause disturbances of blood circulation and morphological reorganization of neuroendocrine bodies, in particular, a cerebellum which is a target under the influence of factors of different origin $[4,14]$. This organ of the central nervous system is a multifunctional component of the brain, which is responsible not only for motor control, but participates in cognitive functions, afferent and behavioral reactions, the dynamics of emotional and mental state, their changes [3, 19]. It is in the neurocytes of the cerebellar cortex that structural and functional changes occur that cause organ dysfunction [8, 11]. As a result of the stress response, there is heterogeneity of central neurocytes - Purkinje cells, which form the ganglion layer, in the cytoplasm of which the amount of Nissl chromatophilic substance decreases, its enlightenment and vacuolation occur $[12,16]$. According to modern research, a day after the action of the thermal factor, the microcirculatory tract is transformed due to the entry of toxic substances into the blood from the area of the burn injury. Neuro-glio-capillary ratios of the cerebellar cortex change, which are characterized by a violation of the blood- 
brain barrier, which includes the capillary wall and one of the types of glial cells $[1,2,17]$.

Therefore, the aim of the study was to establish histological changes in the structural components of the cerebellar cortex one day after the experimental thermal injury.

\section{Materials and methods}

The experiments were performed on 20 adult white male rats, which were kept in standard vivarium conditions on a balanced diet. Animal care and all manipulations were carried out in accordance with the rules of the Strasbourg "European Convention for the Protection of Vertebrate Animals Used for Research and Other Scientific Purposes" and the "General Ethical Principles of Animal Experiments" (Kyiv, 2013).

Grade III burns were applied under thiopental under sodium anesthesia with two copper plates heated in boiled water to a temperature of $97-100^{\circ} \mathrm{C}$ on the epilated surface of the skin of the back of the animal for 30 seconds. The size of the affected area was $18-20 \%$ of the body surface. Experimental animals were decapitated for 1 day of the experiment. For histological examination, pieces of cerebellar tissue were removed and fixed in a $10 \%$ solution of neutral formalin; alcohol, dehydrated and poured into paraffin blocks. To obtain semi-thin sections (1-2 $\mu \mathrm{m})$ and for electron microscopic examination, pieces of cerebellar tissue were fixed in $2.5 \%$ glutaraldehyde solution, postfixed with $1 \%$ osmium tetroxide solution on phosphate buffer. Further processing was performed according to conventional methods. Semi-thin sections made on an LKB-3 ultramicrotome were stained with methylene blue, and ultra-thin sections were contrasted with uranyl acetate and lead citrate according to the Reynolds method [6]. Histological specimens were examined using a MIKROmed SEO SCAN optical microscope and photodocumented using a Vision CCD Camera with a histological specimen image output system. Electron microscopic study was performed in an electron microscope PEM-125K.

\section{Results}

Microscopic studies revealed that on the first day after the experimental thermal injury there is a preservation of angioarchitectonics of the cerebellar cortex and high functional activity of neurons and glia cells (Fig. 1). Stellar and basket-like cells of the molecular layer are characterized by a preserved structure. Stellar neurons, which lie in the upper third of the layer, have a light, rounded nucleus in the karyoplasm of which is dominated by euchromatin, but the boundaries of the perikaryon with the nucleus are not clearly contoured. Some cells have pericellular edema. Basket-like cells have an irregular shape, in the cytoplasm there is a nucleus.

Signs of cell polymorphism are observed in the ganglion layer. Among Purkinje normochromic cells there are

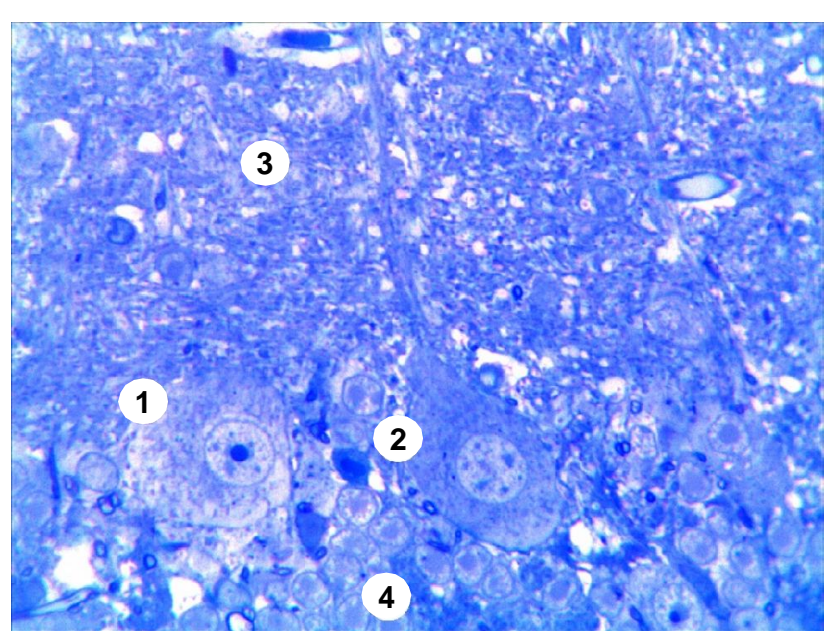

Fig. 1. Microscopic changes of Purkinje cells of the ganglion layer of the cerebellar cortex 1 day after experimental thermal injury. Hypochromic (1) and normochromic (2) neurocytes, molecular (3) and granular (4) layers. Methylene blue stain. $\times 400$.

hypochromic and single sharply hypochromic. Such neurons have a light neuroplasm and a nucleus with enlightened karyoplasm, there are a small number of lumps of chromatophilic substance Nissl. Signs of pericellular edema and partial tigrolysis were found in such neurons. Thickening, enlightenment and edema of Purkinje cell processes are noted, and there were changes in the shape of their perikaryons. The nuclei of hypochromic neurons in the neuroplasm are sometimes eccentrically located, containing one or more nucleoli, which are compacted and hyperchromic. Such signs indicate the activity of synthetic processes in neurons and the initial signs of adaptive reactions to the action of exogenous factor and excessive release of burn toxins into the blood plasma as a result of endogenous intoxication. Populations of granular neurocytes do not undergo significant changes at the optical level, in general, its preservation is observed. Grain cells are tightly arranged, most perikaryons are rounded, but sometimes there are elongated neurons. The nuclei are located mainly in the center of the cell, intensely stained, indicating a tendency to hyperchromia.

Submicroscopically, it was found that after one thermal injury, most Purkinje cells of the ganglion layer had an electron-bright neuroplasm, which corresponded to the phenomenon of tigrolysis and hypochromia, established at the microscopic level. Electron-transparent karyoplasm and small osmophilic lumps of heterochromatin are present in round or round-oval nuclei. The outer and inner nuclear membranes are relatively flat, in some places there was an expansion of the perinuclear space (Fig. 2).

Dilated tubules of the granular endoplasmic reticulum are observed in the neuroplasm, they are partially fragmented. The number of ribosomes fixed to the membranes of the granular endoplasmic reticulum was significantly reduced. At the same time in a neuroplasm there were few polysomes, they are unevenly located. Some 


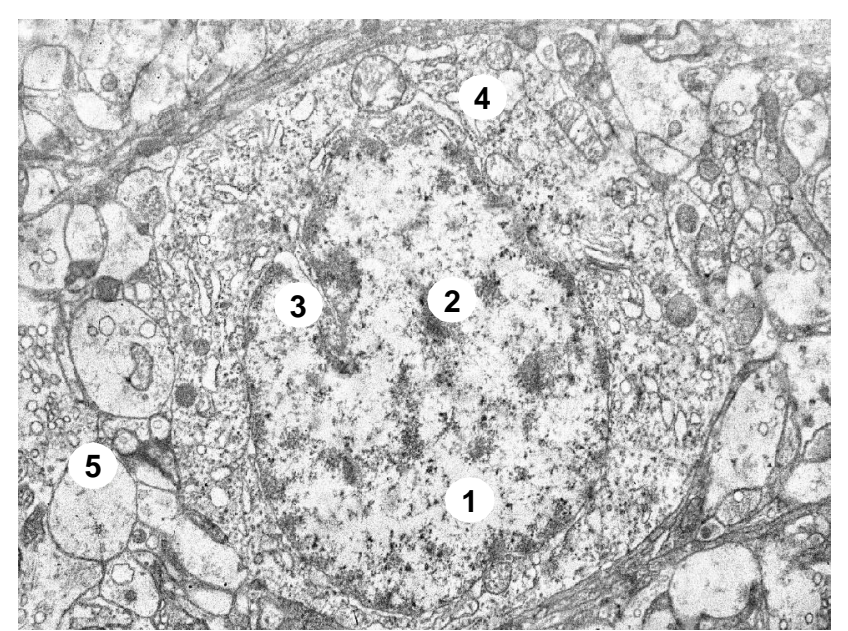

Fig. 2. Ultrastructural state of the hypochromic neurocyte of the molecular layer 1 day after the experimental thermal injury. Nucleus (1) with accumulations of heterochromatin in karyoplasm (2), intussusception of karyolemma (3), unevenly thickened tubules of the granular endoplasmic reticulum (4), edema of the neuropil (5). x10 000 .

of them formed small clusters, which alternated with areas of enlightenment of the cytoplasm. They are more often present near the nucleus and are absent on the periphery of neurons. The ultrastructure of the Golgi complex has changed, its tanks are expanding, their disordered arrangement and bubbles of various sizes have been observed. The content of primary and secondary lysosomes increased. Significant changes in mitochondria were detected, which are hypertrophied, and their matrix is enlightened, partially fragmented cristae.

At the optical level, it was found that one day after the experimental thermal injury there are violations of hemodynamics of the organ. Vessels of a hemomicrocirculatory channel are filled with blood, stasis and aggregation of erythrocytes in the form of coin columns are observed (Fig. 3A). The lumen of some hemocapillaries is narrowed due to the collapse of the walls, which in some areas are not clearly contoured and thinned.

The initial signs of destruction of the wall of hemocapillaries were manifested primarily by ultrastructural changes of endothelial cells (Fig. 3B). Their nuclei are hypertrophied, round-oval with shallow intussusception of karyolemma membranes. An enlarged perinuclear space was found in some nuclei. The karyoplasm mainly contained euchromatin, but lumps of heterochromatin were found near the karyoplasm. The nucleoli are rare, they are small and dense. Paranuclear in the organelle zone were found thickened, dilated loose tubules and tanks of the endoplasmic reticulum and Golgi complex, large vesicles and vesicles. Peripheral, cytoplasmic areas of cells were characterized by edema, enlightenment and a decrease in the number of caveolae and micropinocytic vesicles. On the luminal surface there were few, low microvilli. The basement membrane was swollen, thickened, or thinned in some areas.

It is established that the characteristic microenvironment for the functioning of neurons in the layers of the cerebellar cortex is the presence of gliocytes, neuropil and components of the hemomicrocirculatory tract. One day after the simulated experiment, changes are observed in macroglia, which is represented by oligodendrocytes, which were found in each layer, Bergman's gliocytes in the ganglion layer, protoplasmic astrocytes of the granular layer. At the ultrastructural level, the irregular shape of perikaryons, edema of the processes, increase in the area of their cytoplasm is determined. Euchromatin predominates in the nuclei, heterochromatin is located mainly marginally near the karyolemma, which has local intussusception. The perinuclear space is enlarged in some areas. The cytoplasm is electron light or electron
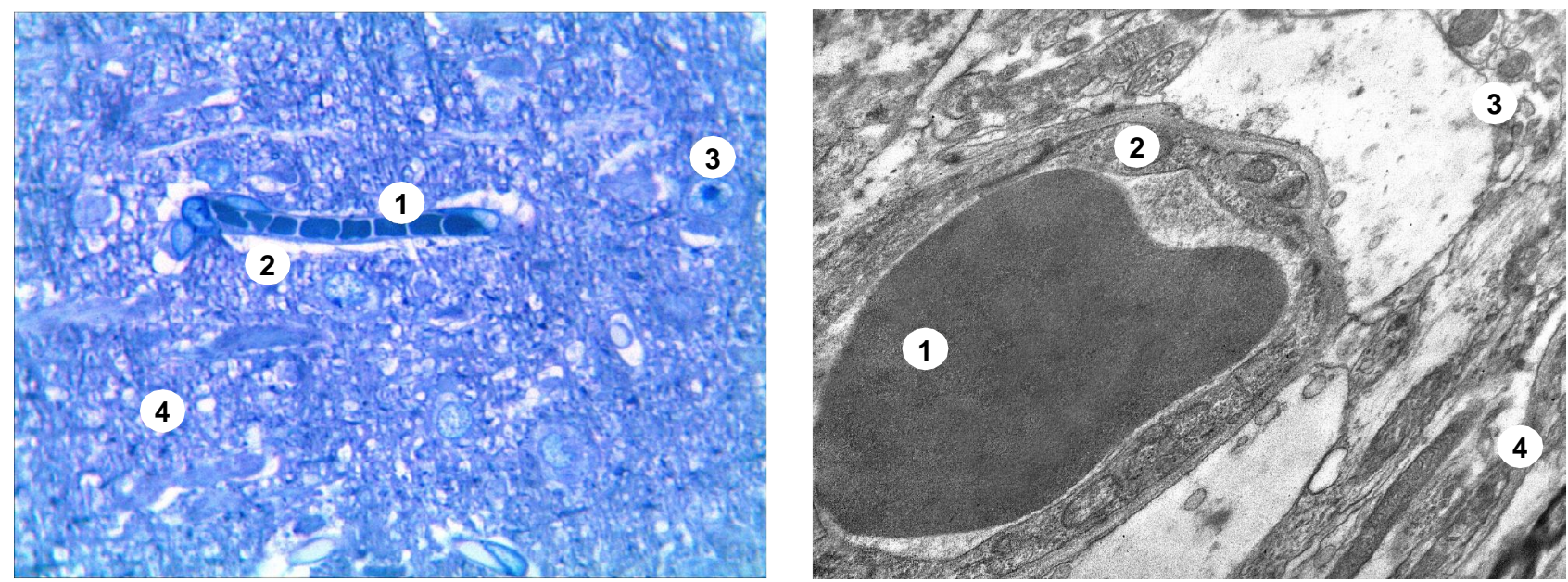

Fig. 3. Histological and ultrastructural changes of hemocapillaries of the cerebellar cortex 1 day after experimental thermal trauma. A erythrocyte in the lumen (1), perivascular edema (2), basket-shaped neurocyte of the molecular layer, neuropil (4). Methylene blue stain. x400. B - erythrocytes in the lumen (1), caveolae and microbubbles in the cytoplasm (2), astrocytic leg (3), neuropil (4). Electronogram. $\mathrm{x} 11000$. 


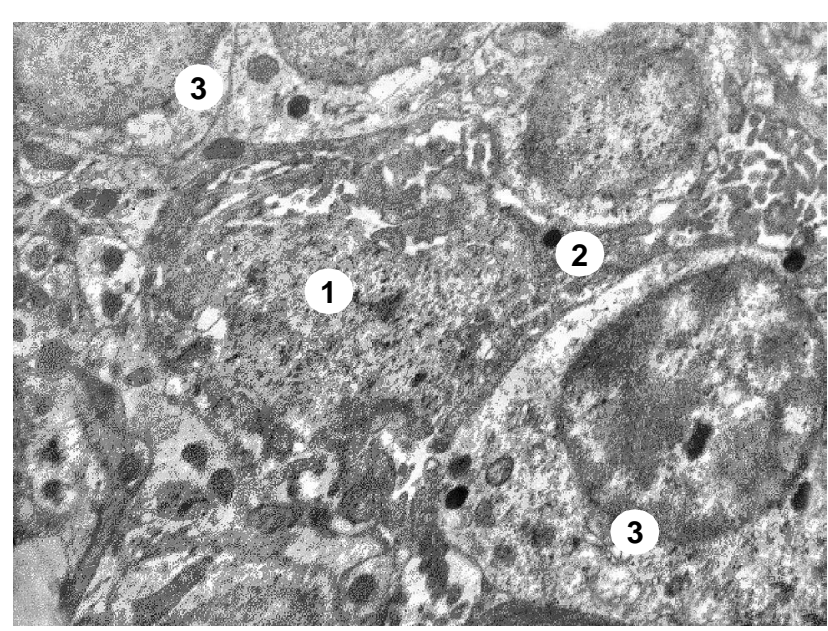

Fig. 4. Ultrastructural changes of astroglia of the cerebellar cortex granular layer. The nucleus of the protoplasmic astrocyte (1), thin processes (2), grain cells (3). x8 000.

dark with a few organelles with signs of destruction. Some mitochondria have an altered shape, their cristae in the enlightened matrix have a disturbed structure. The tubules of the granular endoplasmic reticulum are dilated, vacuolated (Fig. 4).

\section{Discussion}

The results of our studies of the components of the cerebellar cortex at the optical and submicroscopic levels in experimental thermal trauma are to some extent consistent with the available data from the literature. We found that one day after the experiment, reactive changes occur in the components of the microcirculatory tract and there is a reorganization of Purkinje cells of the ganglion layer. There is plethora, stasis formation and erythrocyte coordination, and sometimes hemocapillaries with narrowed lumens. Such changes correspond to the results obtained by A. M. Bekesevich, where the author found that after 2 weeks of the experimental effect of nalbuphine there are the first violations in the structure of the cerebellar cortex of rats, namely the development of microangiopathies [9]. This indicates the reaction of the links of the hemomicrocirculatory tract to the introduction of opioids, which is the basis for the development of systemic structural

\section{References}

[1] Allen, N. J., \& Lyons, D. A. (2018). Glia as architects of central nervous system formation and function. Science, 362(6411), 181-185. doi: 10.1126/science.aat0473

[2] Batiuk, M. Y., Martirosyan, A., Wahis, J., de Vin, F., Marneffe, C., Kusserow, C., \& Holt, M. G. (2020). Identification of regionspecific astrocyte subtypes at single cell resolution. Nature Communications, 11(1), 1-15. doi:10.1038/s41467-01914198-8

[3] Bilash S. M., Pronina O. M., \& Kononov B. S. (2020). Сучасні погляди на процеси реомоделювання структурних компонентів мозочка за умов дії комплексу хімічних речовин. [Modern representations about processes of re-modeling of structural components of the cerebell under conditions of changes. Our studies have shown that heterogeneous changes occur primarily in Purkinje cells, among cell populations which are dominated by hypochromic neurons. These results are to some extent consistent with studies conducted by Morozov Yu. E. and others [10], which confirm the fact that in one day there is enlightenment and vacuolation of the neuroplasm, the authors note that single neurons with signs of hyperchromatolysis and karyopyknosis indicate severe destructive processes in the cerebellum on the background of thermal trauma.

Submicroscopically, we found that one day after the experimental thermal trauma in neurocytes there is a preservation of synthetic processes, which are manifested by the predominance of euchromatin in the karyoplasm, but there is heterochromatin which is located marginally. In the cytoplasm among the organelles there are violations, the tubules of the granular endoplasmic reticulum are unevenly thickened, some mitochondria are swollen. According to Ivanochko V.M. et al [7] in the early posthypothermic period, ultrastructural changes in neurons tend to reactive processes, which to some extent correspond to our research. The cytoplasmic matrix is enlightened. Ribosomes and polysomes are scattered in the hyaloplasm. The granular endoplasmic reticulum is dilated, differentiated in the form of dilated tubules. There is a reduction of the Golgi complex. Mitochondria are swollen, enlarged, the matrix is enlightened.

In further researches it is planned to carry out morphometric researches of parameters of components of a cerebellar cortex under the conditions of experimental thermal trauma and application of correcting factors.

\section{Conclusion}

1. One day after thermal trauma to the skin, experimental animals showed initial violations of the blood-brain barrier of the cerebellar cortex, which are adaptive-compensatory in nature.

2. The initial, destructive, changes of neuro-glialcapillary relations occurring primarily on their damage to the walls of hemocapillaries and manifested by disruption of the micro- and ultrastructure of the main cells of the cerebellum - Purkinje, neurocytes of molecular and granular layers, neuroglyocytes, intra- and pericellular edema.

action of the complex of chemicals]. Вісник проблем біологіi i медицини - Bulletin of problems of biology and medicine, 1(155), 20-25. doi: 10.29254/2077-4214-2020-1-155-20-25

[4] Duke, J. M., Randall, S. M., Fear, M. W., Boyd, J. H., Rea, S., \& Wood, F. M. (2019). Burn induced nervous system morbidity among burn and non-burn trauma patients compared with non-injured people. Burns, 45(5), 1041-1050. doi: 10.1016/ j.burns.2018.06.006 45

[5] Greenhalgh, D. G. (2019). Management of Burns. New England journal of medicine, 380(24), 2349-2359. doi: 10.1056/ nejmra1807442

[6] Horalskyi, L. P., Khomych, V. T., \& Kononskyi, O. I. (2005). Основи гістологічної техніки та морфофункціональних 
методів дослідження в нормі та при патології [Fundamentals of histological technique and morphofunctionalmethods of research in normal and pathology]. Державний агроекологічний університет - State Agroecological University. Житомир: Полісся - Zhytomyr: Polissya.

[7] Ivanochko, V. M., Hrechyn, A. B., \& Pastukh, M. B. (2013). Особливості морфофункціонального стану мозочка в ранні терміни постгіпотермічного періоду. [Features of morphofunctional states of cerebellum in early terms of posthypothermic period]. Галицький лікарський вісник Galician Medical Bulletin, 1(20), 33-35.

[8] Kononov, B. S. (2020). Структурна організація мозочку лабораторних тварин в нормі та у порівняльно-видовому аспекті. [Structural organization of the cerebella of laboratory animals in the norm and in the comparative special aspect]. Вісник проблем біолоаії і медицини - Bulletin of problems of biology and medicine, 4(158), 272-276. doi: 10.29254/20774214-2020-4-158-272-276

[9] Makar, В. Н., \& Bekesevych, А. М. (2015). Морфологічні особливості мозочка білого щура в нормі та за умов двотижневого введення опіоїду. [Morphological features of the white rat's cerebellum in norm and under the influence of opioid during 2 weeks]. Науковий вісник Ужгородського універcumeту, серія "Медицина" -Scientific Bulletin of Uzhhorod University, series "Medicine", 2(52), 20-23.

[10] Morozov, Yu. E., Dorosheva, Zh. V., Gornostaev, D. V., Koludarova, E. M., \& Pigolkin, Yu. I. (2018). The morphological characteristic of the cerebellar cortex in the case of a burning injury. Forensic Medical Expertise, (4), 24-27. doi: 10.17116/ sudmed201861424

[11] Olopade, F. E., Femi-Akinlosotu, O., Adekanmbi, A. J., Ajani, S. \& Shokunbi, M. T. (2020). Neurobehavioural changes and morphological study of cerebellar purkinje cells in kaolin induced hydrocephalus. Anatomical Science International, 96(1), 8796. doi: 10.1007/s12565-020-00561-z

[12] Perez-Pouchoulen, M., VanRyzin, J. W., \& McCarthy, M. M. (2015). Morphological and phagocytic profile of microglia in the developing rat cerebellum. eNeuro, 2(4), 0036-15. doi:

\subsection{3/ENEURO.0036-15.2015}

[13] Porter, C., Tompkins, R. G., Finnerty, C. C., Sidossis, L. S., Suman, O. E., \& Herndon, D. N., (2016). The metabolic stress response to burn trauma: current understanding and therapies. Lancet, 388(10052), 1417-1426. doi: 10.1016/S01406736(16)31469-6

[14] Thibaut, A., Shie, V. L., Ryan, C. M., Zafonte, R., Ohrtman, E. A., Schneider, J. C., \& Fregni, F. (2020). A review of burn symptoms and potential novel neural targets for non-invasive brain stimulation for treatment of burn sequelae. Burns, 47(3), 525-537. doi: 10.1016/j.burns.2020.06.005

[15] Tirado-Esteban, A., Seoane, J. L., Serracanta Domenech, J., Aguilera-Saez, J., \& Barret, J. P. (2020). Sensory alteration patterns in burned patients. Burns, 46(8), 1729-1736. doi: 10.1016/j.burns.2019.08.005

[16] Wallauer, M. M., Huf, F., Tortorelli, L. S., Rahmeier, F. L., Carvalho, F. B., Meurer, R. T., \& da Cruz Fernandes, M. (2018). Morphological changes in the cerebellum as a result of ethanol treatment and cigarette smoke exposure: A study on astrogliosis, apoptosis and Purkinje cells. Neuroscience Letters, (672), 70-77. doi: 10.1016/j.neulet.2018.02.047 13;672:70-77

[17] Williams, A., Gow, A., Kilpatrick, S., Tivers, M., Lipscomb, V., Smith, K., \& Mellanby, R. J. (2020). Astrocyte lesions in cerebral cortex and cerebellum of dogs with congenital ortosystemic shunting. J Vet Sci, 21(3), e44. doi: 10.4142/jvs.2020.21.e44

[18] Ye, H., \& De, S. (2017). Thermal injury of skin and subcutaneous tissues: A review of experimental approaches and numerical models. Burns, 43(5), 909-932. doi: 10.1016/ j.burns.2016.11.014

[19] Zeisel, A., Hochgerner, H., Lonnerberg, P., Johnsson, A., Memic, F., van der Zwan, J., \& Linnarsson, S. (2018). Molecular Architecture of the Mouse Nervous System. Cell, 174(4), 999-1014.e22. doi: 10.1016/j.cell.2018.06.021

[20] Zuo, K. J., Medina, A., \& Tredget, E. E. (2017). Important Developments in Burn Care. Plastic and Reconstructive Surgery, 139(1), $120 \mathrm{e}-138 \mathrm{e}$ doi: 10.1097/ prs.0000000000002908 